\title{
Kreml i krig: Ruslands brug af militær magt
}

\author{
Niels Bo Poulsen \& Jørgen Staun (red.) \\ København: Djøf Forlag 2018 \\ 328 sidor. ISBN 9788757439496
}

Recenserad av Gudrun Persson [forskningsledare, FOI, Stockholm, Gudrun.Persson@foi.se]

Att studera rysk militär förmåga och Rysslands användning av militär makt ansågs i många år vara en rätt perifer syssla - särskilt i akademiska sammanhang. Efter 2014 har detta ändrats. Rysslands agerande i Ukraina, där man med vapenmakt ändrade Europas gränser, innebar ett bryskt uppvaknande - inte minst för väst, som i många fall nästan helt rustat ner sin Rysslandskunskap.

$\mathrm{Nu}$ utkommer även ett danskt översiktsverk om det ryska militära agerandet som behandlar hela perioden från Sovjetunionens upplösning. Kreml $i$ krig består av fjorton kapitel skrivna av åtta danska forskare. Niels Bo Poulsen och Jørgen Staun är inte bara redaktörer utan har själva skrivit och medverkat i flera av kapitlen. De noterar att boken som publicerades 2018 - i en dansk forskningsmiljö - är en nyhet. Anslaget är brett med det uttalade syftet att visa ett mångfacetterat Ryssland, med en utrikes- och säkerhetspolitik som påverkas av olika intressen och drivkrafter över tiden. Gott så.

Tre teoretiska ramverk används för att skapa struktur i antologin: den brittiska forskaren Mary Kaldors teori om nya krig (New Wars), strategisk kultur samt hybridkrigföring. Dessa tre angreppssätt beskrivs och problematiseras i egna kapitel. Nykrigsteorin används för att analysera krigen i Tjetjenien, Centralasien, Transnistrien och Nagorno-Karabach. Teorin om strategisk kultur ligger till grund för fallstudierna om krigen i Georgien, Ukraina och Syrien. För hybridkrigföringen har man valt att studera utvecklingen i Baltikum och Östersjön där, menar författarna, det finns en påtaglig risk för en kommande militär konflikt. Två kapitel behandlar övergripande den ryska resursbasen i form av militärreformen, ombeväpningsprogrammet, utbildning och rekrytering, samt den ryska ekonomiska utvecklingen och medielandskapet i Ryssland. Ett kapitel diskuterar styrkebalansen mellan Ryssland och NATO, och boken avslutas med en analys om utvecklingen i Arktis.

Som i alla antologier finns det kapitel som är bättre än andra. Här vill jag särskilt lyfta fram Stauns kapitel om Arktis - ett av de senaste årens "modeområden» 
avseende rysk säkerhetspolitisk utveckling och militära utbyggnad. Han visar att just vad gäller Arktis är antalet ryska intressenter som kan påverka politiken större än vanligt. Här är det primärt inte en liten krets i den ryska politiska ledningen som fattar snabba beslut. Förutom det nationella säkerhetsrådet, försvars- och utrikesministerierna tillkommer aktörer som energi- och transportministerierna, bolagen Rosneft, Gazprom och Novatek samt enskilda personer. Hur kommer det sig, frågar Staun, att Ryssland just i Arktis främst verkar för samarbete och status quo, när man i andra områden alltmer verkar konfrontatoriskt, regelbrytande och självhävdande? Han menar att de ryska intressena primärt är ekonomiska. Vad gäller den militära utbyggnaden drivs den, enligt Staun, främst av ett försök att balansera gentemot USA/NATO, oron för missilförsvaret (BMD), samt - givetvis - att skydda den nukleära andraslagsförmågan på Kolahalvön. Samtidigt lyfter han ett varningens finger och påpekar att Rysslands säkerhetspolitiska överväganden på senare år har vunnit över varje form av nationalekonomiska intressen. Danmarks territorialanspråk på Ryssland kring Nordpolen lämnades in 2014 och förväntas kunna lösas inom 8-10 år. Om så inte sker skulle Danmark kunna komma att stå med ett ouppklarat territoriellt anspråk kring Nordpolen mot ett revisionistiskt Ryssland.

Det teoretiska ramverket fungerar delvis bra, samtidigt som författarna är väl medvetna om att de olika teorierna inte får stå i vägen för varandra. De ska främst ses som några »olika blickar på ett Ryssland som ständigt förändras», vilket är en pragmatisk och tydlig inställning. Det största problemet är användningen av hybridkrigföring som teoretiskt ramverk. Det är, vilket också sägs, ett västligt begrepp. Att då applicera det som en utarbetad rysk teori blir - i mina ögon - diskutabelt. Risken för spegelseende är uppenbar, liksom feltolkningar av det ryska agerandet vilket kan få oönskade konsekvenser. Dessutom kan det verka som om den ryska doktrinutvecklingen är färdig och klar (det talas till och med om "Gerasimovdoktrinen»), vilket är långt ifrån fallet. Sedan generalstabschefen Valerij Gerasimovs artikel från 2013 har mycket hänt på det området. Den ryska hotbilden, vilket är väsentligt för doktrinutvecklingen, behandlas inte samlat utan finns utspridd på olika ställen. Till kapitlets fördel ska sägas att det reder ut mycket av begreppsförvirringen och klargör åtminstone vad författarna menar med hybridkrigföring. De noterar även att de olika militära och icke-militära medlen har funnits i den ryska verktygslådan under lång tid, men att det nu finns ett kvalitativt nytt fokus i deras tillämpning - inte minst beroende på den tekniska utvecklingen och dagens snabba kommunikation.

De två kapitel som behandlar resursbasen och försöker svara på frågorna vilken slagkraft de ryska Väpnade styrkorna har och hur starkt Ryssland är (kap. 5 och 6) hade vunnit på en större skärpa. Nu är det alltför många områden som berörs högst ytligt, till exempel berörs knappast alls den reform som rör utbildningssystemet. Kapitlet om styrkan behandlar ekonomin och medielandskapet, men utelämnar helt de statliga satsningarna på militärpatriotisk fostran och på att skriva om historien. Dessa strävanden utgör en betydande beståndsdel i Rysslands sökande efter en nationell identitet. 


\section{PERSSON}

Med detta sagt, som en första översikt över ämnesområdet är Kreml $i$ krig en läsvärd genomgång av hur Ryssland använder sitt militära maktmedel. Orden som brukar tillskrivas den tyske kanslern Otto von Bismarck skulle kunna sammanfatta hela boken: »Ryssland är varken så starkt eller svagt som hon verkar.» 